\title{
Sero-prevalence of Fowl Typhoid and Pullorum Disease from Apparently Healthy Chickens in Eastern Ethiopia \\ Genet Tadele ${ }^{1}$, Biruhtesfa Asrade ${ }^{2 *}$, Gizachew Bayleyegn ${ }^{1}$, Mohammed sanni Ali ${ }^{3}$
}

${ }^{1}$ College of Veterinary Medicine, Haramaya University, Dire Dawa, Ethiopia

${ }^{2}$ School of Veterinary Medicine, Hawassa University, Ethiopia

${ }^{3}$ Colleges of Veterinary Medicine and Agriculture, Addis Ababa University, Ethiopia

\begin{abstract}
A study was conducted on 393 apparently healthy exotic and local chickens reared at different management systems in eastern Ethiopia in order to determine the sero-prevalence of Salmonella Gallinarum and Salmonella Pullorum. To achieve this objective, blood samples were collected and the expressed sera were used from the selected chickens for antibody detection. The samples were from Haramaya University (309 chickens) and Dire Dawa (84 chickens). Subsequently, serum slide agglutination test was employed. Based on this, the overall prevalence of Salmonella Gallinarum and Salmonella Pullorum was 125/393 (31.8\%). The prevalence of each farm was $95(30.7 \%)$ Haramaya University farm, 13 (32.5\%) Dire Dawa University farm and 17 (38.6\%) local breeds of Dire Dawa. Moreover, the study has recorded higher prevalence in back yard chickens as compared to chickens reared at intensive farms. However, associated risk factors have not been found statistically significant at $(P$ value $<$ 0.05). In conclusion, the present study revealed Salmonella Gallinarum and Salmonella Pullorum were prevalent in both production systems. Therefore, further epidemiological investigations on these pathogens and implementation of control measures are mandatory.
\end{abstract}

Keywords: Sero-prevalence; Serum slide agglutination; Salmonella Gallinarum; Salmonella Pullorum; Chickens

\section{Introduction}

Poultry play an important role in the livelihood of poor rural households in many developing countries including Ethiopia [1]. In Ethiopia, the total poultry population is estimated to be 50 million [2]. Recently commercial flocks have been emerged in urban and peri-urban areas in central parts of the country [1]. However, the country is not benefitted from the sector. This is due to different contributing factors, among which are low genetic potential of the indigenous breeds, high prevalent of infectious diseases and traditional feeding practice [3-5].

Previously different poultry diseases have been recorded in exotic and local chicken in Ethiopia; the major diseases include New castle disease, coccidiosis, salmonellosis, chronic respiratory disease and nutritional deficiency [5-8]. Fowl Typhoid and Pullorum Disease are among the most important diseases of poultry. These conditions are caused by Salmonella Gallinarum and Salmonella Pullorum respectively [5]. Both diseases are a serious concern in growing and adult poultry and show similar clinical manifestation. The controls of these diseases are complicated by vertical transmission. Hens can become sub clinically infected carriers, and pass the infection to their embryos in the egg [5-7]. Fowl Typhoid and Pullorum Disease can be diagnosed by culturing on standard media from affected birds (brilliant green, XLD agars, selenite $\mathrm{F}$ of tetrathionate broth for enrichment). Detection of the organism and differentiation of the biovars can be done by serologic tests. These tests including serum agglutination test are important to detect infected flocks and estimate the prevalence of infection within a flock [8]. Although Fowl Typhoid and Pullorum Disease are known to cause marked economic loss, up to now few studies have been done in Ethiopia [9]. Presently, there is few sero-prevalence reports exist regarding Salmonella Gallinarum and Salmonella Pullorum [10,11]. In connection to this, further investigation of both diseases using sound serological tests will have significant contribution to show the status in the poultry production sector. Therefore, the objectives of this study are to determine sero-prevalence of Fowl Typhoid and Pullorum Disease and to assess the effect of associated risk factors.

\section{Materials and Methods}

\section{Study area}

The study was carried out in poultry farms of Haramaya and Dire Dawa Universities. Haramaya University is located in the Eastern Ethiopia, approximately $510 \mathrm{Km}$ from Addis Ababa. The elevation is 2000 meter above sea level and the area receives an average annual rainfall $900 \mathrm{~mm}$. Dire Dawa University is located at $515 \mathrm{~km}$ from Addis Ababa, at an elevation of 950 - 1250 meter above sea level. The Average annual rainfall varies from $604 \mathrm{~mm}$ in the dry "Kola" zone to $900 \mathrm{~mm}$ in the mid land "Weinadega" zone. The temperature ranges from $28.1^{\circ} \mathrm{C}$ to $34.6^{\circ} \mathrm{C}[12,13]$.

\section{Study population}

The target population was apparently healthy white leg horn and fiam (Egyptian breed) breed chickens in poultry farms of Haramaya and Dire Dawa Universities including local and exotic breed from Dire Dawa. A total of 353 commercial chickens and 40 chickens of local poultry comprising different age group, management system, and breed and production level were included in this study.

\section{Study design}

The sample size was determined using win episcope 2 which is improved epidemiological data soft ware for veterinary medicine [14].

*Corresponding author: Biruhtesfa Asrade, School of veterinary medicine Hawassa University, Ethiopia, Tel: +251911033444; E-mail: biruhta@gmail.com

Received November 03, 2013; Accepted December 18, 2013; Published December 21, 2013

Citation: Tadele G, Asrade B, Bayleyegn G, Ali MS (2014) Sero-prevalence of Fowl Typhoid and Pullorum Disease from Apparently Healthy Chickens in Eastern Ethiopia. J Veterinar Sci Technol 5: 156. doi:10.4172/2157-7579.1000156

Copyright: @ 2014 Tadele G, et al. This is an open-access article distributed under the terms of the Creative Commons Attribution License, which permits unrestricted use, distribution, and reproduction in any medium, provided the original author and source are credited. 
Citation: Tadele G, Asrade B, Bayleyegn G, Ali MS (2014) Sero-prevalence of Fowl Typhoid and Pullorum Disease from Apparently Healthy Chickens in Eastern Ethiopia. J Veterinar Sci Technol 5: 156. doi:10.4172/2157-7579.1000156

Page 2 of 3

Sample size for intensive production was determined using cluster sample formula [11]. Since no research work has been done before in the study areas, $50 \%$ prevalence and $95 \%$ confidence interval were considered.

\section{Study methodology}

Approximately $2-3 \mathrm{ml}$ of blood sample was collected from the wing vein and the blood in the plane vacutainer tube was put in slant position at room temperature. After $12 \mathrm{hrs}$ of clotting, the sera were subjected to centrifugation at $1000 \mathrm{rpm}$ for 10 minutes [15]. Finally, clarified sera were stored in deep freeze until it was tested. Serum slide agglutination test was performed following the test procedure described by Quinn [16]. All harvested sera and the reagent were brought to room temperature $\left(22 \pm 5^{\circ} \mathrm{C}\right)$ before use. $30 \mu \mathrm{l}$ of crystal violet stained Salmonella Gallinarum antigens and equal volume of the serum were added on sterile slide. Thereafter, the two contents were mixed gently by rocking and rotating it for about 2-3 minutes. And then, presence or absence of agglutination reactions was checked. Any level of agglutination is considered as positive.

\section{Data analysis}

Data were classified, filtered and coded using MS Excel 5. SPSS version 17 was deployed to generate statistical associations. The descriptive statistics were used to determine the prevalence of Salmonella Gallinarum in both local and commercial chickens Pearson chi-square was used to evaluate the statistical significance of Salmonella Gallinarum and associated risk factors. A probability value $<0.05$ was considered statistically significant.

\section{Result}

The overall prevalence of Fowl Typhoid and Pullorum Disease in the chicken of the study area was $31.9 \%$ (125/393). Based on the study, chickens from Haramaya were with a prevalence of 30.7\% (95/309), while the prevalence in Dire Dawa was $32.5 \%$ and $38.6 \%$ for the commercial and the local breeds, respectively (Table 1). According to the breeds classification Egyptian fayoumis are less affected with prevalence of $25 \%$ while local chickens from Dire Dawa relatively highly affected $38.64 \%$ when compared with other chickens (Table 1). Based on this study all age group were similarly affected by the disease (Table 2). Furthermore, the association of potential risk factors for seropositivity is presented in Table 2.

\section{Discussion}

Poultry has been the major reservoir of the Salmonellosis. There are epidemiological studies published on prevalence of Fowl Typhoid and Pullorum Disease in Ethiopia [3,11]. However, the sero prevalence of these diseases based on serum agglutination test has not been studied in eastern ethiopia. In present study the serum agglutination response to Salmonella Gallinarum and Salmonella Pullorum in apparently healthy chickens is relatively high when compare to the previous report in poultry in other countries.

The possible causes of the high prevalence of this study are the facts that both diseases are complicated by vertical and horizontal transmission occur via the respiratory and oral routes. Hens might become sub clinically infected carriers and pass the infections to their embryos in the egg. The other important facts are chickens are natural hosts and highly adapted for these pathogens. In addition, Salmonella Gallinarum and Salmonella Pullorum survive in a favorable environment from months up to several years and this characteristic contributes persistent infection in these hosts. Previous studies on the basis of bacteriological and culturing have confirmed the above facts $[5,7,17,18]$. A Sero prevalence study from Nigeria has reported

\begin{tabular}{|l|c|c|c|}
\hline \multirow{2}{*}{ Origin } & Number of chickens examined & \multicolumn{2}{|c|}{ SAT } \\
\hline HU(Exotic-intensive) & 309 & 95 & Negative \\
\hline DU(Exotic-intensive)v & 40 & 13 & 214 \\
\hline Diredawa(Local-back yard) & 44 & 17 & 27 \\
\hline Total & 393 & 125 & 27 \\
\hline
\end{tabular}

HU: Haramaya University; DU: Dire Dawa University, SAT= Serum agglutination test.

Table 1: Sero-prevalence of Salmonella Gallinarum and Salmonella pullorum with origin.

\begin{tabular}{|c|c|c|c|c|c|c|}
\hline Variables & Total Examined & No of positive & Prevalence (\%) & $x^{2}$ & $P$ - Value & $95 \% \mathrm{Cl}$ \\
\hline Age & & & & 0.279 & 0.597 & $0.584-1.363$ \\
\hline$>70$ weeks & 200 & 61 & 30.50 & & & \\
\hline$<70$ weeks & 193 & 64 & 33.16 & & & \\
\hline Breed & & & & 1.789 & 0.409 & $0.416-1.211$ \\
\hline WLH & 309 & 98 & 31.72 & & & \\
\hline Fayoumis & 40 & 10 & 25.00 & & & \\
\hline Local & 44 & 17 & 38.64 & & & \\
\hline \multicolumn{7}{|l|}{ Sex } \\
\hline Male & 218 & 69 & 31.65 & \multirow[t]{2}{*}{0.002} & \multirow[t]{2}{*}{0.963} & \multirow[t]{2}{*}{$0.659-1.847$} \\
\hline Female & 175 & 56 & 32 & & & \\
\hline \multicolumn{7}{|l|}{ Production level } \\
\hline $55-80$ eggs/year & 349 & 108 & 31.00 & \multirow[t]{2}{*}{0.983} & \multirow[t]{2}{*}{0.321} & \multirow[t]{2}{*}{$0.377-1.379$} \\
\hline 280 eggs/year & 44 & 17 & 38.64 & & & \\
\hline
\end{tabular}

WLH: White leg horn; $x 2$ : Chi-square. 
Citation: Tadele G, Asrade B, Bayleyegn G, Ali MS (2014) Sero-prevalence of Fowl Typhoid and Pullorum Disease from Apparently Healthy Chickens in Eastern Ethiopia. J Veterinar Sci Technol 5: 156. doi:10.4172/2157-7579.1000156

Page 3 of 3

similar prevalence (37.9\%) from two different managements systems [19]. Moreover, research reports conducted on chicken carcasses have also revealed high prevalence and both diseases are long-established worldwide [7,20-22]. However, in Africa, moderate prevalence (16\%) of these diseases has been published by Mbuko [23] as compare to the present study.

Previously, there are few reports on Fowl Typhoid and Pullorum Disease in Ethiopia, in particular, regarding the sero prevalence. These preceding works have indicated that the diseases were highly prevalent and economically important diseases in chickens in central and northern part of the country $[3,10,11,24]$. However, the high prevalence rate of the present study was inconsistent with the previous survey on salmonella contamination in chickens' carcass and giblets [25] with moderate prevalence rate of $21.1 \%$. The difference could be due to the methods that are applied and also the tests used. Here it is good to remember that the possibility of false positive and false negative results on slide agglutination (SAT). Serological tests are normally designed to detect a limited range of Salmonella serovars or serogroups. It is well recognised that some animals with a positive serological response may no longer be infected with Salmonella organisms. Chickens that are actively excreting salmonellae may be serologically negative in the early stages of disease and some individual infected chickens never seroconvert. Poutry that are serologically positive 6 may have ceased to excrete salmonellae although circulating immunoglobulin concentrations may remain high. Other chickens on the farm may still be infected. Serologically negative poultry may result from a recent infection causing excretion before immunoglobulin production is maximal, or infection with less invasive serovars. Animals that have been infected recently would eventually be detected serologically by an appropriate monitoring programme throughout the life of the flock but there are often cost limitations to the application of effective monitoring programmes [26].

In conclusion, the present study revealed the overall sero-prevalence of Fowl Typhoid and Pullorum Diseases were prevalent in both production systems. Therefore, further epidemiological investigations; proper management practice, application of prevention and control measures are recommended.

\section{References}

1. Pagani P, Wossene A (2008) Review of the new features of the Ethiopian poultry sector, Biosecurity implications. Food and Agriculture Organization of the United Nations (FAO)

2. CSA (2011) Federal Democratic Republic of Ethiopia Central Statistical Agency. Agricultural Sample Survey Report on Livestock and Livestock Characteristics. Addis Ababa Stat Bull 2: 505

3. Dinka H, Chala R, Dawo F, Bekana E, Leta S (2010) Major Constraints and Health Management of Village Poultry Production in Rift Valley of Oromia, Ethiopia. American-Eurasian J Agric \& Environ Sci 9: 529-533.

4. Moges, F, Tegegne A, Dessie T (2010) Indigenous chicken production and marketing systems in Ethiopia: Characteristics and opportunities for marketoriented development. IPMS (Improving Productivity and Market Success) of Ethiopian Farmers Project Working Paper 24. Nairobi, Kenya: ILRI.

5. World Organization for Animal Health (OIE) (2012) In: Terrestrial Manual 2012 Anonymous: Fowl typhoid and Pullorum disease. Paris, France.

6. Ivanics E, Kaszanyitzke E, Glavits R, Szeredi L, Szakall S, et al. (2008) Acute epidemic disease in laying hen flocks, caused by Salmonella Gallinarum. Magyar Allatorvosok Lapja 130: 611-617.

7. Ta YT, Nguyen TT, To PB, Pham da X, Le HT, et al. (2012) Prevalence of Salmonella on chicken carcasses from retail markets in Vietnam. J Food Prot 75: 1851-1854

8. Proux K, Humbert F, Jouy E, Houdayer C, Lalande F, et al. (2002) Improvements required for the detection of Salmonella Pullorum and Gallinarum. Can J Vet Res 66: 151-157

9. Hagos A, Eshetu Y, WeldeMeskel M (2003) Identification of Major Infections of Local chicken of central Ethiopia. Bull Anim Hlth Prod Afri 51: 95-101.

10. Afera B, Regassa F, Issa A (2012) Seroprevalence of fowl typhoid in selected areas east of Shewa, Ethiopia REDVET. Revista Electrónica de Veterinaria 13 $1-13$.

11. Endris M, Taddesse F, Geloye M, Degefa T, Jibat T (2013) Sero and media culture prevalence of Salmonellosis in local and exotic chicken, Debre Zeit, Ethiopia. African Journal of Microbiology Research 7: 1041-1044.

12. Central Statistical Authority (CSA) of Ethiopia.

13. DDAEPA (2011) Dire Dawa Administration Program of Adaptation to Climate Change (DDAEPA), Dire Dawa, Ethiopia.

14. Thrusfield M (2001) Veterinary epidemiology, department of Veterinary Clinical study University of Edinburgh.

15. Beard CW (1989) Serologic procedures in a laboratory manual for the isolation and identification of Avian pathogens, 3rd ed. American association of Avian pathologist, Kendall/Hunt publishing Co, Pp 201-207.

16. Quinn PJ, Markey BK, Carter ME, Donnelly WJ, Leonard FC (1994) Veterinary Microbiology and Microbial Disease. Blackwell Publishing, London.

17. Calnek BW, Barness HJ, Bread CW, Reid, WM, Yoder HW (1991) Diseases of poultry. (9th Edn) IOWA State University Press/AMES, USA.

18. Basnet HB, Kwon HJ, Cho SH, Kim SJ, Yoo HS, et al. (2008) Reproduction of fowl typhoid by respiratory challenge with Salmonella Gallinarum. Avian Dis 52: $156-159$

19. Okwori AES, Hashimu Ga, Adetunji JA, Okeke IO, Junaid SA (2007) Serologica Survey of Salmonella Gallinarum Antibody in Chickens around Jos, Plateau state, Nigeria. Online J Healtth Allied Scs 2: 2

20. Nógrády N, Kardos G, Bistyák A, Turcsányi I, Mészáros J, et al. (2008) Prevalence and characterization of Salmonella infantis isolates originating from different points of the broiler chicken-human food chain in Hungary. Int J Food Microbiol 127: 162-167.

21. Yang B, Xi M, Wang X, Cui S, Yue T, et al. (2011) Prevalence of Salmonella on raw poultry at retail markets in China. J Food Prot 74: 1724-1728.

22. Alali WQ, Gaydashov R, Petrova E, Panin A, Tugarinov O, et al. (2012) Prevalence of Salmonella on retail chicken meat in Russian Federation. J Food Prot 75: 1469-1473.

23. Mbuko IJ, Raji MA, Ameh J, Saidu L, Musa WI, et al. (2009) Prevalence and seasonality of fowl typhoid disease in Zaria-Kaduna State, Nigeria. Journal of Bacteriology Research 1: 001-005.

24. Berhea N, Aferaa B, Abebea N, Tesfaya A, Kalayoua S (2012) Seroprevalence of infection with Salmonella pullorum in local chickens (criollos) and trade in exotic areas of Mekelle, northern Ethiopia. REDVET. Revista Electrónica de Veterinaria 13

25. Molla B, Mesfin A (2003) A survey of Salmonella contamination in chicken carcass and giblets in Central Ethiopia. Revue Méd Vét 154: 267-270.

26. World Organisation for Animal Health (OIE) (2010) Salmonellosis. OIE Manual of Terrestrial Animal. Chapter 2.9.9. 8-10. 